Article

\title{
Impact of Producer's Environmental Performance on Consumers and Retailers Simultaneously in the Indonesian Retail Environment
}

\author{
Muhamad Ibnu Fajar ${ }^{1, *}$, Haryoto Kusnoputranto ${ }^{2}$, Raldi Hendro T. S. Koestoer ${ }^{1}$ and Misri Gozan ${ }^{3}$ (I) \\ 1 School of Environmental Science, University of Indonesia, Salemba Raya No. 4, Jakarta 10430, Indonesia; \\ raldy.hk@ui.ac.id \\ 2 Department of Environmental Health, Faculty of Public Health, University of Indonesia, \\ Depok 16424, Indonesia; haryotok@ui.ac.id \\ 3 Department of Chemical Engineering, Faculty of Engineering, New Campus, University of Indonesia, \\ Depok 16424, Indonesia; mgozan@ui.ac.id \\ * Correspondence: muhamad.ibnu91@ui.ac.id
}

Citation: Fajar, M.I.; Kusnoputranto,

H.; Koestoer, R.H.T.S.; Gozan, M.

Impact of Producer's Environmental

Performance on Consumers and

Retailers Simultaneously in the

Indonesian Retail Environment.

Sustainability 2022, 14, 1186. https:/ /

doi.org/10.3390/su14031186

Academic Editors:

Pedro Cuesta-Valiño,

Pablo Gutierrez-Rodriguez and

Antoni Serra Cantallops

Received: 24 December 2021

Accepted: 19 January 2022

Published: 21 January 2022

Publisher's Note: MDPI stays neutral with regard to jurisdictional claims in published maps and institutional affiliations.

Copyright: () 2022 by the authors. Licensee MDPI, Basel, Switzerland. This article is an open access article distributed under the terms and conditions of the Creative Commons Attribution (CC BY) license (https:// creativecommons.org/licenses/by/ $4.0 /)$.

\begin{abstract}
Producers improve environmental performance to reduce the release of post-production waste. The positive environmental performance of producers is expected to influence consumer environmental attitudes positively, specifically toward post-consumption waste. However, research is deficient in exploring the impact of producer environmental performance (PEP) on retailer-consumer relationship quality (RCRQ) and consumer purchasing behavior (CPB) simultaneously to drive consumer environmental attitude (CEA) in the retail environment. Therefore, this study aims to examine the effect of PEP on RCRQ and CPB simultaneously to drive CEA in the retail environment. The survey was conducted at 17 retail outlets for 150 consumers of lubricant producers in the industrial city of Gresik, Indonesia. Partial Least Square analysis indicates that consumers perceive $\mathrm{PEP}$ has positive effects on CEA, but negatively affects RCRQ and positively affects CPB. Thereby, CPB has a more significant positive effect than RCRQ on CEA. Although RCRQ and CPB have significant positive total effects, $\mathrm{CPB}$ has a more significant indirect effect than RCRQ in mediating the effect of PEP on CEA. This study provides actionable guidance to reduce the negative impact of PEP on RCRQ to enhance the mediating role of RCRQ for more positive consumer environmental attitudes.
\end{abstract}

Keywords: environmental performance; relationship quality; purchasing behavior; environmental attitude; producers; retailers; consumer; Partial Least Square

\section{Introduction}

In recent decades, the rapid growth of automotive demand in developing countries, including Indonesia, has increased the amount of hazardous waste from used lubricating oils that must be disposed of [1]. On the other hand, producers' environmental performance reduces the release of post-production waste at the factory site but cannot affect the release of post-consumption waste outside the factory site [2]. Apart from being the responsibility of producers [3,4], $t$ retailers and consumers are also needed in efforts to reduce the release of post-consumption waste [5,6], including lubricant waste [7,8].

Meanwhile, an Indonesian lubricant producer located in Gresik is participating in a government program on environmental performance and environmental compliance for companies to meet sustainable development goals [9]. This lubricant producer markets lubricating oil for automotive purposes to consumers through retail outlets in Gresik. Consumers of this lubricant producer are assumed to have a higher perception of the green environment, but their behavior shows the opposite [10]. Therefore, the impact of producers' environmental performance on retailers and consumers is meaningful because it can affect the role of retailers and consumers. In the end, it can impact producers' efforts to 
reduce post-consumption waste outside the factory location. Environmental performance affects environmental attitudes [11] and pro-environmental behavior [12]. Thus, producers' environmental performance can drive consumers' environmental attitude [13,14] and consumers' environmental awareness of post-consumption waste as it provides benefits to consumers [15].

In the retail environment, the quality of the retailer-consumer relationship plays an essential role in promoting corporate environmental responsibility to encourage consumers' purchase intention [16]. Therefore, consumer attitudes and behavior can benefit retailers to build relationships with consumers [17]. On the other hand, consumers who consider the benefits of producers' environmental performance in purchasing products [18] demonstrate consumers' sense of responsibility towards the environment [19]. Therefore, producers environmental performance can also represent green product attributes essential to green decision-making [20]. Although producer's environmental performance can drive consumer environmental attitudes in the retail environment, how does the impact of producer's environmental performance on consumer-retailer relationship quality and consumer purchasing behavior drive consumer environmental attitudes? These are the questions of this research.

The sustainability literature has examined the relationship between environmental awareness and consumer green purchasing behavior [21-24]. However, the research focuses only on consumer perception of producers' environmental performance in the retail environment [25-28]. The relationship quality research focuses only on examining the relationship between environmental performance and interfirm relationships, mainly in the supply chain environment [29-32]. Interfirm collaboration is beneficial to a firm's overall environmental performance [33]; this represents a gap in the literature. In this study, the theory of perceived corporate social responsibility as a part of perceived corporate environmental performance [34] is integrated with the theory of retailer-consumer relationship quality $[35,36]$. Therefore, this study describes how the impact of producer's environmental performance on retailer-consumer relationship quality and consumer purchasing behavior drives consumer environmental attitudes. In particular, this study examines the effect of producer environmental performance on retailer-consumer relationship quality and consumer purchasing behavior simultaneously, and the mediating effect of retailer-consumer relationship quality and consumer purchasing behavior drives the effect of producers environmental performance on consumers' environmental attitudes.

\section{Literature Review}

\subsection{Producer Environmental Performance}

The environmental performance of producers using market-based instruments and a command-and-control approach to control pollution should also take other factors into account [37]. While environmental performance has significant differences in firm size and target market, no statistical significance was found in environmental performance involving geographic regions or industry sectors [38]. Further, environmental performance measurement depends on the research questions and samples. Meanwhile, its operationalization depends on the interests of the stakeholder group examined and the time horizon, company or product characteristics, and external factors relevant to stakeholder expectations [39]. Due to perceived corporate social responsibility being a subset of perceived producer's environmental performance, it is plausible to utilize perceived corporate social responsibility indicators in measuring the perceived producer's environmental performance through indicators such as perceived substantial information [40], perceived quality of corporate responsibility [41], and brand trustworthiness [42].

Producers' environmental performance has a positive relationship with green company image. Therefore, it can affect consumer reactions [43] and green consumption [44]. In addition to influencing consumers' environmental attitudes, producer environmental performance increases consumers' concern for the severity of environmental problems [21]. Hence, the proposed hypothesis is as follows: 
Hypothesis 1 (H1). Producer environmental performance positively affects consumer environmental attitudes.

\subsection{The Relationship Quality}

Research has recognized that collaboration in improving environmental and social performance results in sustainable benefits [45]. The fitness of coordination between producers and retailers simultaneously influence the environmental cost and improve environmental performance [46]. Further, producers' high recognition of environmental uncertainty could achieve high service performance by enhancing external integration [47]. However, collaboration in improving environmental performance does not always result in high-quality relationships [48], especially when its impacts include lower financial performance and high environmental management overhead costs for partners [49]. Dissatisfied retailer partners impact channel value, thereby influencing consumer loyalty [50]. Thus, partnerships and flexibility between producers and retailers in responding to consumers' requirements are essential in strengthening relationships between retailers and consumers [51].

The literature has also revealed that a strong retailer can influence producers and consumers because retailers can communicate directly with them [52]. The exchange of information and communication between retailers and consumers [53] and the flexibility of their relationship $[54,55]$ determine the quality of the relationship between retailers and consumers, while partnerships and flexibility of suppliers in serving customers are essential to strengthening relationships with customers. The long-term orientation of the relationship between retailers and consumers is highly expected in ensuring a mutually beneficial relationship [56]. Retailers' low levels of trust in the producers due to uncertainty in their return on investment $[57,58]$ has consequences on perceived service quality and eventually affect the quality of consumer-retailer relationships [59]. Although the relationship quality can create effective marketing [60,61], it depends on the retailer's efforts to bridge both producers' interests and consumers [62]. Hence, the proposed hypothesis is as follows:

Hypothesis 2 (H2). Perceived producer environmental performance negatively affects the retailerconsumer relationship quality.

\subsection{Purchasing Behavior}

Consumer purchasing behavior is the process of consumers purchasing products after going through stages in the decision-making process influenced by various inputs, both from the consumer socio-cultural environment and the marketing efforts by producers $[63,64]$. Meanwhile, consumers' green purchase behavior is a consumption pattern towards green products, including the products made by green producers $[65,66]$. Green purchase behavior is influenced by the urgency of the seriousness of environmental problems, the effectiveness of environmental behavior [67], the environmental responsibility and the concern for self-image in environmental protection efforts, the social environment [68], the role of government [69,70] and green product attributes [71].

Environmental performance contributes to a green corporate image [72]. Consumers with green brand knowledge prefer to make deals with green marketing, which ultimately affects their purchase intentions. The higher the consumer's concern for environmental problems, the higher the consumer's purchase intention for environmentally friendly products, and vice versa [20]. Therefore, a green company image representing environmental performance positively affects consumer reactions to green consumption (Yue et al. 2020). Hence, the proposed hypothesis is as follows:

Hypothesis 3 (H3). Perceived producer environmental performance positively affects consumer purchasing behavior. 


\subsection{Environmental Attitude}

Environmental attitude is an environmental concern formed by beliefs and behavior intention towards the environment [73]. In addition to the crucial construct in environmental psychology, the environmental attitude is also the fundamental concept of environmental and psychological tendencies expressed by evaluating the natural environment [74]. Therefore, the consumer environmental attitude describes the involvement of consumers in caring about environmental activities, including the willingness to pay a premium on green products and green service providers $[75,76]$. A consumer with a robust pro-environmental attitude is likely to consume sustainable products [6], indicating a positive correlation between environmental attitude and the mind's cognitive, affective, and conative aspects [77].

Direct experience with nature influences environmental attitudes and community environmental behavior [78]. Notwithstanding that, price sensitivity is relative, and consumers are still willing to buy green products when the price is different from other, non-green products [79]. Consumers' environmental knowledge, perceived seriousness of environmental problems, interpersonal, collectivism, and long-term orientation positively relate to consumer environmental attitudes [80]. Additionally, the attitude has a relationship with the perceived environmental responsibility and green purchasing behavior [81].

Environmental performance affects environmental attitudes, although it is not always a prerequisite for behavior change [82]. By serving as a liaison between producers and consumers, retailers can help drive the influence of producers' environmental performance on improving consumers' environmental attitudes [5]. Relational communication affects relational satisfaction when retailers build trust, commitment with producers and consumers [83], especially when retailers incur long-term business relationship commitments to return additional investment [12]. Hence, the proposed hypothesis is as follows:

Hypothesis 4 (H4). The retailer-consumer relationship quality has no significant effect on consumers' environmental attitudes.

A consumer's environmental attitude does not always reflect the actual action. Thereby, consumers who have this attitude toward the environment are not always buying environmentally friendly products [84]. However, producer environmental performance reduces environmental impacts due to producer activities [85] to reduce environmental anxiety, ultimately improving pro-environmental behavior intention [86]. In the retail context, green marketing affects green purchase intentions and could benefit from increasing consumer environmental awareness and attitudes [17]. Therefore, the producer's environmental performance affects the purchase intention of green consumers and ultimately increases consumers' environmental awareness and attitudes. Hence, the proposed hypothesis is as follows:

Hypothesis 5 (H5). Consumer purchasing behavior has a significant positive effect on consumers' environmental attitude.

\section{Materials and Methods}

The surveys and direct interviews with the respondents were conducted at the research location to collect primary data. The questionnaire as a research instrument was utilized to collect data and then processed to affirm the hypotheses of this research, as shown in the proposed conceptual model (Figure 1).

\subsection{Instrument Development}

The questionnaire addressed 150 consumers who purchased lubricants at 17 authorized retail outlets of Indonesia's national lubricants producer in Gresik City, East Java province. This lubricant producer also operates a factory in Gresik City, which has been awarded a green rating for environmental performance management based on an assessment from the government [9]. Surveys and interviews of respondents were conducted 
directly at the research location from June to August 2020 (during the pandemic, the survey and interview followed the health protocol). The determination of the number of samples followed the formula of $n>50+8 M$, where $n$ is the number of samples and $m$ is the number of independent variables [87]. This study uses one independent variable. Therefore, the number of samples should be greater than 58 . This study utilizes the selected 100 respondents to fill out the questionnaire using the purposive sampling method [88].

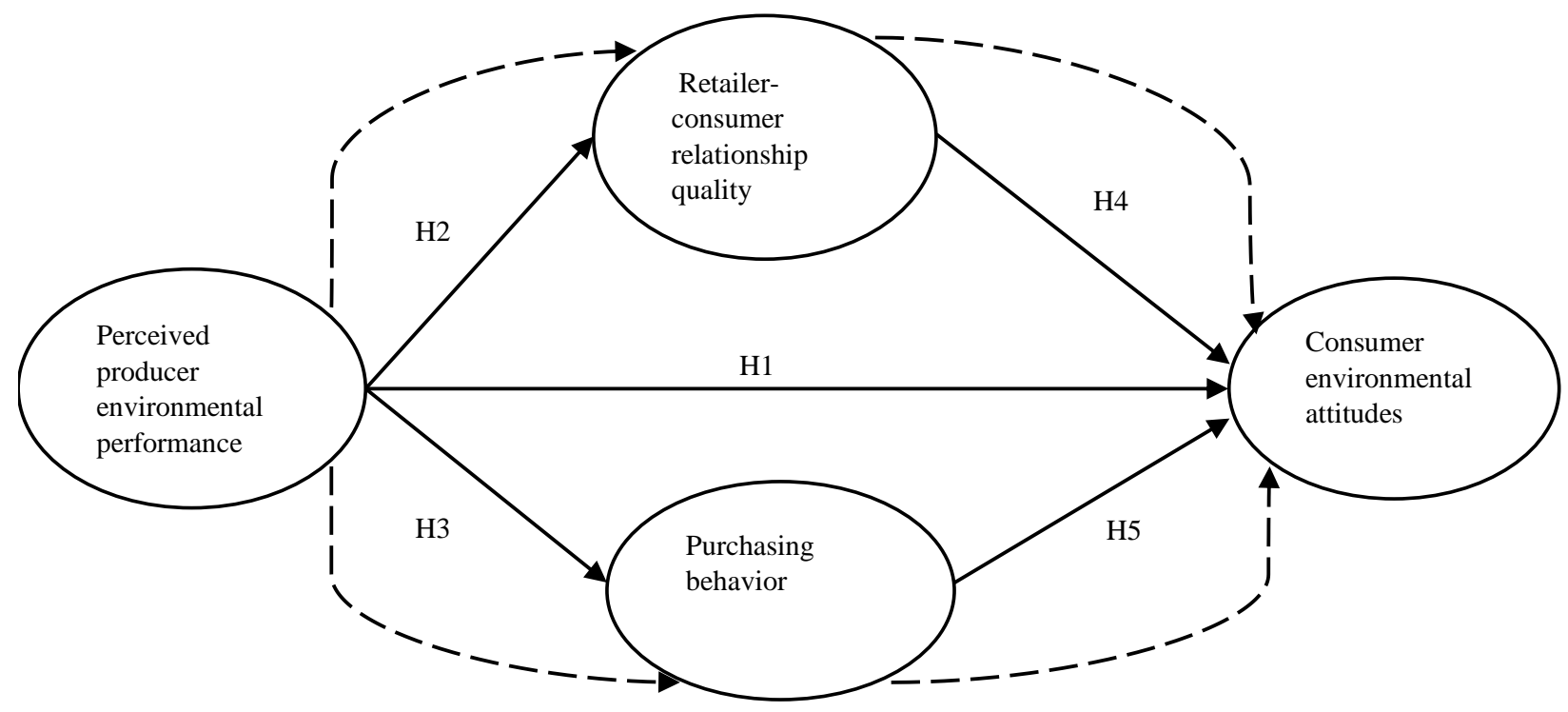

Figure 1. A proposed conceptual model. Solid lines indicate direct effects and dashed lines indicate indirect effects.

The questionnaire consisted of 4 measurable constructs, where each construct had three indicators according to the empirical theory of previous research. Each construct indicator was described in 3 questionnaire items, so that there were 36 questionnaire items in this study. First, the construct of perceived producer's environmental performance had the indicators of perceived substantial information [89], perceived corporate responsibility quality [90], and brand trustworthiness [91]. Second, the relationship quality variable had the indicators of flexibility, long-term relationship orientation, and communication quality [92]. Third, the construct of purchasing behavior had the indicators of social influence [93], product attribute [20], and the role of government [94]. Fourth, the construct of environmental attitudes had the indicators of cognitive, affective, and conative [95].

\subsection{Instrument Selection}

The collected data from respondents were screened using statistical analysis to determine the validity and reliability of questionnaire items as this research. Table 1 shows the statistical analysis results of the research instruments, indicating that the majority of questionnaire items met the criteria of validity ( $r$ count $>r$ table at $5 \%$ significances) and reliability (Cronbach's Alpha > 0.7) [96]. 
Table 1. Questionnaire validity and reliability.

\begin{tabular}{|c|c|c|c|}
\hline Description & $\begin{array}{l}\text { Number of Items with } \\
\text { Pearson Correlation Value > } \\
\text { r-Table at Significance }=5 \%\end{array}$ & $\begin{array}{c}\text { Cronbach's Alpha Values } \\
(>0.7)\end{array}$ & Remarks \\
\hline $\begin{array}{c}\text { Perceived producer } \\
\text { environmental performance }\end{array}$ & 9 of 9 items & 0.851 & $\begin{array}{c}9 \text { of } 9 \text { questionnaire items are } \\
\text { valid and reliable }\end{array}$ \\
\hline $\begin{array}{l}\text { Retailer-consumer relationship } \\
\text { quality }\end{array}$ & 8 of 9 items & 0.811 & $\begin{array}{c}8 \text { of } 9 \text { questionnaire items are } \\
\text { valid and reliable }\end{array}$ \\
\hline Consumer purchasing behavior & 9 of 9 items & 0.862 & $\begin{array}{c}9 \text { of } 9 \text { questionnaire items are } \\
\text { valid and reliable }\end{array}$ \\
\hline Consumer environmental attitude & 8 of 9 items & 0.749 & $\begin{array}{c}8 \text { of } 9 \text { questionnaire items are } \\
\text { valid and reliable }\end{array}$ \\
\hline
\end{tabular}

Note: sample size $=150$.

\section{Results}

The analysis of this research utilized Partial Least Square (PLS) modeling. In addition to minimizing standard errors and increasing the measure of goodness of fit due to nonnormal data, the utilization of PLS modeling also achieves higher levels of statistical power for smaller sample sizes to measure the formative construct presence in this multivariate analysis [97]. The PLS modeling was conducted in three stages. First, evaluation of the measurement model measured whether the latent constructs met the criteria of internal consistency reliability, discriminant validity, the convergent validity of the constructs, and indicator reliability. The construct indicators' collinearity was also measured due to the presence of the latent variable with formative indicators. Second, the evaluation of the structural model was to test the hypotheses and interpret the strength and direction on each construct relationship by measuring the path coefficient, T-statistics, $p$-values, and standard deviation, for both direct effects and indirect effects [98]. Third, the PLS also evaluates the model's goodness of fit by measuring the cross-validated redundancy, the predictive accuracy of the model, the effect size, and the goodness of fit [99].

\subsection{Measure Reliability and Validity}

The constructs of relationship quality, consumer purchasing behavior, and consumer environmental attitudes were modeled as reflective indicators, an approach that assumes these constructs are the cause of the manifest variables. Meanwhile, the construct of perceived producer' environmental performance was modeled as a formative indicator whereby the manifest variables are the cause of the construct [98].

Table 2 shows that the reflective constructs, namely the relationship quality, purchasing behavior, and consumer environmental attitude, resulted in Cronbach's Alpha, AVE value, and composite reliability values exceeding the thresholds of $0.70,0.50$, and 0.80 , respectively. Thus, all reflective constructs met the criteria of internal consistency reliability. Meanwhile, the loading weight values results were more significant than the threshold value of 0.70 . These results strengthened the construct validity. In addition, the HTMT value was measured, with the result exceeding 0.7 . Thus, all reflective constructs met the discriminant validity criteria [97].

Table 2. Construct reliability and validity.

\begin{tabular}{cccccc}
\hline \multirow{2}{*}{ Reflective Construct } & \multicolumn{2}{c}{ Internal Consistency Reliability } & Discriminant Validity & Convergent Validity \\
\cline { 2 - 3 } & Cronbach's Alpha & Composite Reliability & & (HTMT) & 0.876 \\
Relationship quality & 0.859 & 0.934 & 0.936 & 0.807 \\
Purchasing behavior & 0.897 & 0.851 & 0.952 & 0.9627 \\
Environmental attitude & 0.921 & 0.962 & 0.963 & 0.827 \\
\hline
\end{tabular}


The perceived producer's environmental performance construct was the only formative construct in this study. Table 3 shows that the significance of weight values exceeded the thresholds of 0.70 . The Variable Inflation Factor (VIF) values did not exceed the threshold of 5.0, which means that all indicators met the indicator reliability criteria, indicating that the absence of collinearity indicators was due to the presence of the formative construct [97]. Finally, the perceived producer's environmental performance met a formative construct's indicator reliability and collinearity criteria.

Table 3. Indicator reliability and collinearity.

\begin{tabular}{|c|c|c|c|c|c|}
\hline \multirow[b]{2}{*}{ Construct } & \multicolumn{4}{|c|}{$\begin{array}{c}\text { Indicator Reliability } \\
\text { (Significance of Weight) }\end{array}$} & \multirow{2}{*}{$\begin{array}{l}\text { Collinearity } \\
\text { (VIF) }\end{array}$} \\
\hline & $\begin{array}{l}\text { Perceived Producer } \\
\text { Environmental } \\
\text { Performance }\end{array}$ & $\begin{array}{l}\text { Relationship } \\
\text { Quality }\end{array}$ & $\begin{array}{l}\text { Purchase } \\
\text { Behavior }\end{array}$ & $\begin{array}{c}\text { Consumer } \\
\text { Environmental } \\
\text { Attitude }\end{array}$ & \\
\hline \multicolumn{6}{|l|}{$\begin{array}{l}\text { Perceived producer } \\
\text { environmental } \\
\text { performance with } \\
\text { formative indicators: }\end{array}$} \\
\hline $\begin{array}{l}\text { 1. Perceived substantial } \\
\text { information }\end{array}$ & 0.955 & & & & 3.306 \\
\hline $\begin{array}{l}\text { 2. Perceived corporate } \\
\text { responsibility quality }\end{array}$ & 0.917 & & & & 3.306 \\
\hline 3. Brand trustworthiness & 0.951 & & & & 3.306 \\
\hline \multicolumn{6}{|l|}{$\begin{array}{l}\text { Relationship quality with } \\
\text { reflective indicators: }\end{array}$} \\
\hline 1. Flexibility & & 0.928 & & & 2.305 \\
\hline $\begin{array}{l}\text { 2. Long term relationship } \\
\text { orientation }\end{array}$ & & 0.934 & & & 2.305 \\
\hline 3. Communication & & 0.938 & & & 2.305 \\
\hline \multicolumn{6}{|l|}{$\begin{array}{l}\text { Purchasing behavior with } \\
\text { reflective indicators: }\end{array}$} \\
\hline 1. Social influence & & & 0.909 & & 2.956 \\
\hline 2. Product attribute & & & 0.956 & & 2.956 \\
\hline 3. Government role & & & 0.939 & & 2.956 \\
\hline \multicolumn{6}{|l|}{$\begin{array}{c}\text { Environmental attitude } \\
\text { with reflective indicators }\end{array}$} \\
\hline 1. Cognitive & & & & 0.941 & 3.688 \\
\hline 2. Affective & & & & 0.964 & 3.688 \\
\hline 3. Conative & & & & 0.962 & 3.688 \\
\hline
\end{tabular}

\subsection{Hypotheses Testing}

Table 4 shows that perceived producer' environmental performance has a negative effect but not significant on the relationship quality $(\beta=-0.191 ; p$-value $=0.001$; T-Statistics $=3.399)$ and has a positive significant effect on consumer purchase behavior $(\beta=0.173 ; p$-value $=0.028$; T-statistics $=2.202)$. Furthermore, relationship quality has negative effect but not significant on consumer environmental attitude $(\beta=-0.024 ; p$-value $=0.428$; T-statistics $=0.793$ ). Consumer purchase behavior has a positive significant effect on consumer environmental attitude $(\beta=0.887 ; p$-value $=0.001$; T-statistics $=22.468)[98]$. 
Table 4. Direct effects.

\begin{tabular}{|c|c|c|c|c|}
\hline Relationship Path & Path Coefficient $(\beta)$ & $p$-Values & T-Statistics & $\begin{array}{l}\text { Standard } \\
\text { Deviation }\end{array}$ \\
\hline $\begin{array}{l}\text { Producer environmental } \\
\text { performance-consumer } \\
\text { environmental attitude }\end{array}$ & 0.149 & 0.035 & 2.119 & 0.070 \\
\hline $\begin{array}{l}\text { Producer environmental } \\
\text { performance-Relationship } \\
\text { quality }\end{array}$ & -0.191 & 0.001 & 3.399 & 0.056 \\
\hline $\begin{array}{c}\text { Producer environmental } \\
\text { performance-Purchasing } \\
\text { behavior }\end{array}$ & 0.173 & 0.079 & 2.202 & 0.079 \\
\hline $\begin{array}{c}\text { Relationship } \\
\text { quality-Environmental } \\
\text { attitude }\end{array}$ & -0.024 & 0.428 & 0.793 & 0.030 \\
\hline $\begin{array}{l}\text { Purchasing } \\
\text { behavior-Environmental } \\
\text { attitude }\end{array}$ & 0.887 & 0.001 & 22.468 & 0.039 \\
\hline
\end{tabular}

Note: PLS bootstrapping result at the 5000 sub-sample setting and 5\% significance.

The mediating effect of retailer-consumer relationship quality and purchasing behavior on the relationship between producer environmental performance and consumer environmental attitudes was tested to result in total effects by accumulating the direct and indirect effects. Table 5 shows the results of the mediating effects of relationship quality and purchasing behavior in this study. A bootstrap analysis with 5000 resamples indicated that the total effects of retailer-consumer relationship quality $(\beta=0.154 ; p$-value $=0.037$; T-statistics $=2.015)$ and consumer purchasing behavior $(\beta=0.302 ; p$-value $=0.031$; T-statistics $=2.192)$ in mediating the relationship between producer environmental performance and consumer environmental attitudes were both positive and significant. However, specific indirect effect of the relationship between producer environmental performance and consumer environmental attitudes via consumer purchasing behavior $(\beta=0.153$; $p$-value $=0.029$; T-statistics $=2.185$ ) was more significant than via retailer-consumer relationship quality $(\beta=0.005 ; p$-value $=0.418 ;$ T-statistics $=0.810)[97]$.

Table 5. Mediating effects.

\begin{tabular}{ccccc}
\hline Relationship Path & Effects & Path Coefficient $(\boldsymbol{\beta})$ & $\boldsymbol{p}$-Values & T-Statistics \\
\hline \multirow{3}{*}{ PEP-RCRQ-CEA } & Direct effect & 0.149 & 0.035 & 2.119 \\
& Indirect effect & 0.005 & 0.418 & 0.810 \\
& Total effect & 0.154 & 0.037 & 2.015 \\
\hline \multirow{3}{*}{ PEP-CPB-CEA } & Direct effect & 0.149 & 0.035 & 2.119 \\
& Indirect effect & 0.153 & 0.029 & 2.185 \\
& Total effect & 0.302 & 0.031 & 2.192
\end{tabular}

Note: PEP is producer environmental performance, RCRQ is retailer-consumer relationship quality, CEA is consumer environmental attitudes, and $\mathrm{CPB}$ is consumer purchasing behavior.

Table 6 shows the results of the hypotheses testing. Producer environmental performance positively affects consumer environmental attitude (H1). Producer environmental performance positively affects consumer purchasing behavior (H3). However, producer environmental performance negatively affects retailer-consumer relationship quality $(\mathrm{H} 2)$. Further, retailer-consumer relationship quality does not mediate the effect of producer environmental performance on consumer environmental attitude $(\mathrm{H} 4)$ as the $p$-values $>0.05$ for $5 \%$ significance. On the other hand, consumer purchasing behavior positively mediates the effect of producer environmental performance on consumer environmental attitude (H5). 
Table 6. Hypotheses and results.

\begin{tabular}{|c|c|c|c|c|}
\hline Hypotheses & Path Coefficient $(\beta)$ & $p$-Values & T-Statistics & Result \\
\hline $\begin{array}{l}\text { Producer environmental } \\
\text { performance positively } \\
\text { affects consumer } \\
\text { environmental attitude }\end{array}$ & 0.149 & 0.035 & 2.119 & $\begin{array}{l}\text { Hypothesis } \\
\text { accepted }\end{array}$ \\
\hline $\begin{array}{c}\text { Producer environmental } \\
\text { performance negatively } \\
\text { affects relationship } \\
\text { quality }\end{array}$ & -0.191 & 0.001 & 3.399 & $\begin{array}{l}\text { Hypothesis } \\
\text { accepted }\end{array}$ \\
\hline $\begin{array}{l}\text { Producer environmental } \\
\text { performance positively } \\
\text { affects consumer } \\
\text { purchasing behavior }\end{array}$ & 0.173 & 0.079 & 2.202 & $\begin{array}{l}\text { Hypothesis } \\
\text { accepted }\end{array}$ \\
\hline $\begin{array}{l}\text { Relationship quality } \\
\text { does not mediate the } \\
\text { effect of producer } \\
\text { environmental } \\
\text { performance on } \\
\text { consumer }\end{array}$ & -0.024 & 0.428 & 0.793 & $\begin{array}{l}\text { Hypothesis } \\
\text { accepted }\end{array}$ \\
\hline $\begin{array}{l}\text { environmental attitude } \\
\text { Consumer purchasing } \\
\text { behavior positively } \\
\text { mediates the effect of } \\
\text { producer environmental } \\
\text { performance on } \\
\text { consumer } \\
\text { environmental attitude }\end{array}$ & 0.887 & 0.001 & 22.468 & $\begin{array}{l}\text { Hypothesis } \\
\text { accepted }\end{array}$ \\
\hline
\end{tabular}

\subsection{Goodness of Fit}

Finally, the measuring the cross-validated redundancy to assess the inner model' predictive relevance $(0>\mathrm{Q} 2>1)$, the predictive accuracy of the model by measuring the coefficient of determination $(\mathrm{R} 2=0.25$ is weak; $\mathrm{R} 2=0.50$ is moderate: $\mathrm{R} 2=0.75$ is substantial), the effect size ( $\mathrm{f} 2=0.02$ is small effect; $\mathrm{f} 2=0.15$ is a medium effect: $\mathrm{f} 2=0.35$ is a large effect), and the goodness of fit by measuring the Standardized Root Mean Square Residual (SRMR $<0.08)^{99}$. The analysis results indicate the model had a high level of predictive relevance $(\mathrm{Q} 2=0.717)$ and substantial predictive accuracy $(\mathrm{R} 2=0.789)$, had a medium effect size ( $\mathrm{f} 2=0.38$ ), and a high level of goodness of fit (SRMR $=0.053)$. The analysis results indicate that the model met the goodness of fit modeling criteria [98].

Figure 2 shows the final structural equation model as the results of this research. Producer environmental performance (PEP) with the indicators of perceived substantial information (PSI), perceived corporate responsibility quality (PCSQ) and brand trustworthiness (BTW) meet construct validity and reliability as the formative construct. Further, the construct of retailer-consumer relationship quality (RCRQ) with the reflective indicators of flexibility (FLEX), long-term relationship orientation (LTR) and communication quality $(\mathrm{COM})$, the construct of consumer purchasing behavior $(\mathrm{CPB})$ with reflective indicators of social influence (SOC), product attribute (ATR) and government role (GOV), and the construct of consumer environmental attitude (CEA) with reflective indicators of cognitive (COG), affective (AFFE) and conative (CON) also met the criteria of construct validity and reliability. Finally, the path relationship between constructs answered all the research hypotheses. 


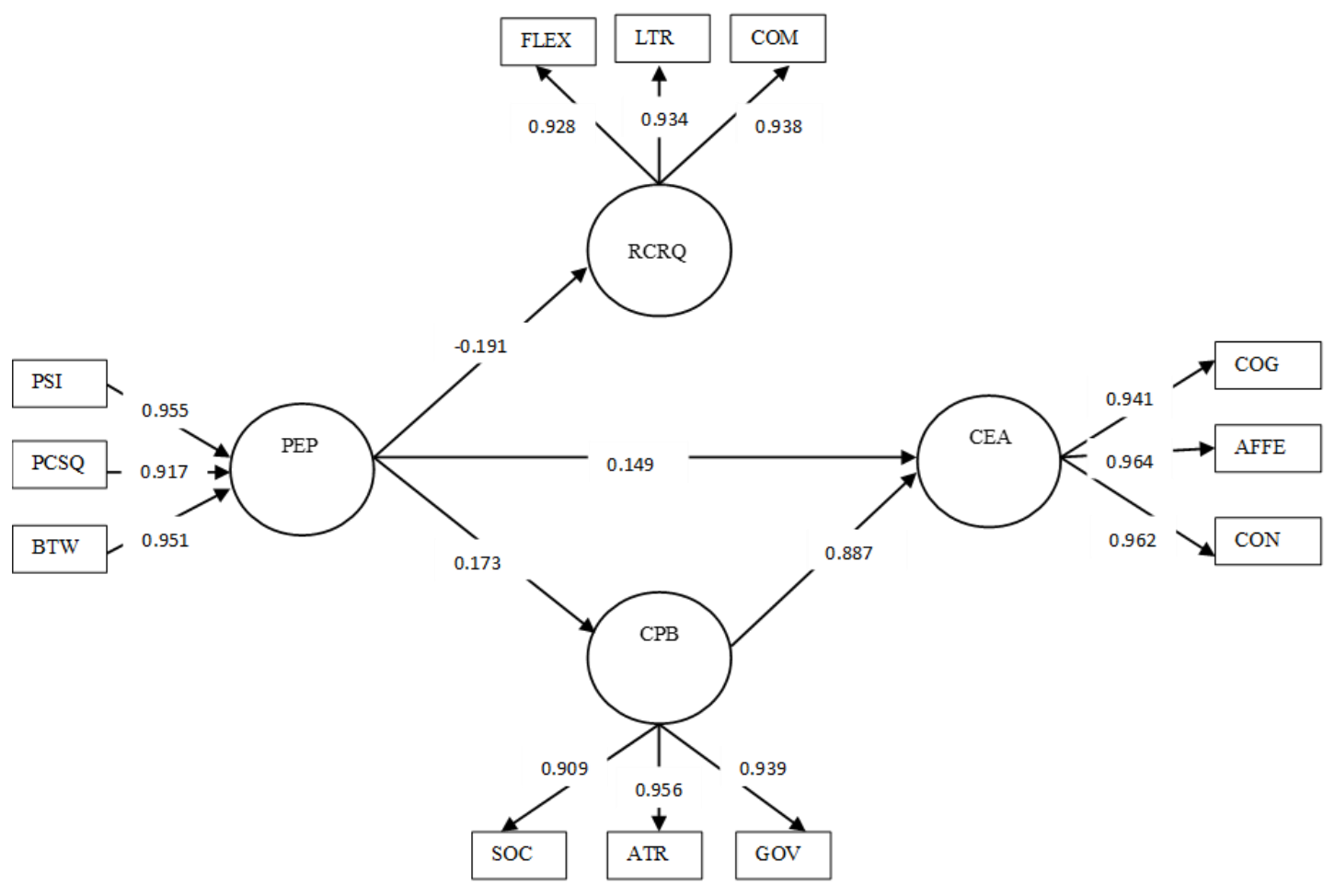

Figure 2. Structural equation model. Solid lines indicate direct effects.

\section{Discussion}

The study findings show how producers' environmental performance harms the quality of the retailer-consumer relationship but improves purchasing behavior. In addition, consumer purchasing behavior significantly mediates the effect of producer environmental performance on consumer environmental attitudes, while the consumer-retailer relationship quality does not. The implications to theory and practice are next explored to illustrate the state of the art of this research.

\subsection{Implication to Theory}

This research contributes to the literature on environmental management. First, this study extends the previous research that examined the effect of perceived environmental performance on various consumer behaviors in retail environments [25] by linking theories of perceived environmental performance with relationship quality, purchasing behavior and environmental attitudes. In the marketing context, the findings of this study support previous research that explored the roles of producers, retailers and consumers in affecting channel performance [100]. However, the findings of this study demonstrate an irrelevant result to previous studies indicating that satisfaction, trust and commitment, as a subset of relationship quality, have a positive mediating effect on the relationship between corporate environmental responsibility and consumer purchase intentions [16]. Therefore satisfaction, trust, and commitment play an essential role in mediating effect of the retailer-consumer relationship quality on the relationship between producer's environmental performances on consumer's environmental attitudes.

Second, this study adds a new stream in consumer studies by integrating theory on the effect of producer environmental performance toward relationship quality with theory on consumer purchasing behavior. However, the findings of this study are irrelevant to previous studies that perceived that environmental uncertainty positively affects inter-firm collaboration when the communication process is involved [29]. Therefore, the communication process plays a crucial role in encouraging a more positive influence on perceived environmental performance in retailer-consumer relationship quality. 
Third, this research adds new information to the retailing literature on the influence of producer environmental performance on the quality of the relationship between producers and retailers based on consumer perceptions by developing theory on the relationship between perceived quality relationship and consumer satisfaction and loyalty. However, the previous research found that consumer interactions with the environment and service personnel (at retail outlets), as the subset of consumer service, positively impacts relationship quality between retailer and consumer [101]. Although this indicates a contradiction with the findings of this study, it also shows that perceived customer service has a positive effect on relationship quality. Therefore, the level of service provided by retailers has an impact on the mediating role of retailers in encouraging the influence of producer environmental performance on consumer environmental attitudes.

\subsection{Implication to Practice}

The study results can guide producers (manufacturers) in analyzing the impact of environmental performance on retailer-consumer relationship quality and purchasing behavior simultaneously to drive consumer environmental attitude. The results of this study can also be of reference to producers who intend to collaborate with retailers to improve producer environmental performance by leveraging the role of retailers and consumers. However, the implication for the producers and retailers in a collaboration to improve environmental performance is as follows: First, the producer should pay more attention to the retailer's orientation towards long-term relationships as a commitment. Therefore, formal contractual agreements with agreed terms and conditions, especially in terms of a reasonable contract period, reduce retailers' burden as an impact of environmental investment [102].

Second, regular meetings between producers and retailers should be held to enhance consumer satisfaction, especially on perceived producer environmental performance. In addition to discussing cooperative strategies to improve environmental performance, regular meetings also explain to retailers the benefits of building trust, commitment, and responsibility to encourage consumer environmental attitudes [83].

Third, a preliminary study on the impact of producers' environmental performance on retailers and consumers needs to be carried out by producers to identify the objections of retailers and changes in consumer behavior due to the perceived producers' environmental performance. In addition, this preliminary study can also be helpful for producers to evaluate the level of communication and flexibility in their relationships with retailers and consumers so that producers can take further steps to encourage the role of retailers to mitigate the negative impact of their environmental performance on retailer-consumer relationship quality to improve consumer attitudes towards the environment.

\subsection{Limitations and Research Directions}

This study's main contribution is to highlight the effect of perceived producer's environmental performance on retailer-consumer relationship quality, consumer purchase behaviors, and consumer environmental attitudes. However, the location of this research was set one distribution channel of a lubricant brand in an industrial area. Therefore, multi-channels of distribution in a broader area may have different statistical significant results because multi-channels have more complexity and heterogeneous consumers [103]. This limitation creates opportunities for further researchers to examine the impact of environmental performance on the quality of producer-retailer relationships and consumer behavior simultaneously, considering multiple distribution channels of various products in a broader area, even across countries.

The theoretical approach in this study was developed based on measuring consumer perception under conditions in which they were not operationally involved in the activities of producers or retailers, so it may not fully represent the perceived quality of the relationship based on retailer perceptions. Therefore, there is an opportunity for future research to explore the effect of producer environmental performance on the quality of producer-retailer relationships and consumer behavior from retailers' perspectives. 
This study is limited to exploring consumer perceptions of producers with higher environmental performance ratings based on government assessment. However, producers with low or moderate environmental performance ratings are open to exploration for further research. In addition, further research could also examine consumer perceptions on the various levels of environmental performance of a group of producers.

\section{Conclusions}

The environmental performance of lubricant producers impacts retailers and consumers in the lubricant retail environment. Specifically, the environmental performance of lubricant producers improves consumers' environmental performance and purchasing behavior in the city of Gresik. On the other hand, it negatively impacts the quality of retailer-consumer relationships. In this case, the mediating role of consumer purchasing behavior in driving the effect of the environmental performance of lubricant producers on consumer environmental attitudes is more significant than the quality of the retailerconsumer relationship. Consumers perceived that the negative impact of the environmental performance of lubricant producers on the quality of the retailer-consumer relationship was caused by retailer spending by investments in promoting the environmental performance of the lubricant producer to consumers. Burdened retailers have limited resources and bargaining power to request additional investment in promoting the environmental performance of lubricant producers. However, in a broader retail environment context, producer environmental performance may have a different impact on retailers and consumers. Different types of products and characteristics of consumers, or even different marketing channels, may have different statistical significance results. Therefore, this study opens an opportunity for future research that examines the effect of producer environmental performance on retailers and consumers simultaneously in the retail environment.

Author Contributions: M.I.F.: Conceptualization, methodology, formal analysis, review and editing, writing-original draft, visualization; H.K.: conceptualization, methodology, review, supervision; M.G.: conceptualization, methodology, review, supervision; R.H.T.S.K.: conceptualization, methodology, review, supervision; All authors have read and agreed to the published version of the manuscript.

Funding: This research received no external funding.

Data Availability Statement: The data presented in this study are available on request from the corresponding author.

Acknowledgments: The authors are grateful and thankful to the management of an Indonesian lubricant manufacturer who participated in our study.

Conflicts of Interest: The authors declare no conflict of interest. The funders had no role in the design of the study; in the collection, analyses, or interpretation of data; in the writing of the manuscript, or in the decision to publish the results.

\section{References}

1. Oliveira, M.C.; Magrini, A. Life Cycle Assessment of Lubricant Oil Plastic Containers in Brazil. Sustainability 2017, 9, 576. [CrossRef]

2. Nemati, M.; Zheng, Y.; Hu, W. ISO-14001 Standard and Firms' Environmental Performance: Evidence from the U.S. Transportation Equipment Manufacturers. SSRN Electron. J. 2016, 1-30. [CrossRef]

3. Bassi, S.A.; Boldrin, A.; Faraca, G.; Astrup, T.F. Extended Producer Responsibility: How to Unlock the Environmental and Economic Potential of Plastic Packaging Waste? Resour. Conserv. Recycl. 2020, 162, 105030. [CrossRef]

4. Leclerc, S.H.; Badami, M.G. Extended Producer Responsibility for E-Waste Management: Policy Drivers and Challenges. J. Clean. Prod. 2020, 251, 119657. [CrossRef]

5. Vadakkepatt, G.G.; Winterich, K.P.; Mittal, V.; Zinn, W.; Beitelspacher, L.; Aloysius, J.; Ginger, J.; Reilman, J. Sustainable Retailing. J. Retail. 2021, 97, 62-80. [CrossRef]

6. Wang, Y. Promoting Sustainable Consumption Behaviors: The Impacts of Environmental Attitudes and Governance in a Cross-National Context. Environ. Behav. 2017, 49, 1128-1155. [CrossRef]

7. Güerre, A.A. Oil Tax, Subsidies and Extended Producer Responsibility in the Used Oil Market. Int. J. Energy Econ. Policy 2018, 8, 1118. [CrossRef] 
8. Nowak, P.; Kucharska, K.; Kamiński, M. Ecological and Health Effects of Lubricant Oils Emitted into the Environment. Int. J. Environ. Res. Public Health 2019, 16, 3002. [CrossRef]

9. Handoyo, S. The Development of Indonesia Environmental Performance and Environmental Compliance. J. Account. Audit. Bus. 2018, 1, 74. [CrossRef]

10. Deliana, Y.; Rum, I.A. How Does Perception on Green Environment across Generations Affect Consumer Behaviour? A Neural Network Process. Int. J. Consum. Stud. 2019, 43, 358-367. [CrossRef]

11. Tariq, M.; Yasir, M.; Majid, A. Promoting Employees' Environmental Performance in Hospitality Industry through Environmental Attitude and Ecological Behavior: Moderating Role of Managers' Environmental Commitment. Corp. Soc. Responsib. Environ. Manag. 2020, 27, 3006-3017. [CrossRef]

12. Rizzi, F.; Annunziata, E.; Contini, M.; Frey, M. On the Effect of Exposure to Information and Self-Benefit Appeals on Consumer's Intention to Perform pro-Environmental Behaviours: A Focus on Energy Conservation Behaviours. J. Clean. Prod. 2020, 270, 122039. [CrossRef]

13. Baierl, T.M.; Johnson, B.; Bogner, F.X. Assessing Environmental Attitudes and Cognitive Achievement within 9 Years of Informal Earth Education. Sustainability 2021, 13, 3622. [CrossRef]

14. Paço, A.; Rodrigues, R.G. Environmental Activism and Consumers' Perceived Responsibility. Int. J. Consum. Stud. 2016, 40, 466-474. [CrossRef]

15. Taufik, D.; Reinders, M.J.; Molenveld, K.; Onwezen, M.C. The Paradox between the Environmental Appeal of Bio-Based Plastic Packaging for Consumers and Their Disposal Behaviour. Sci. Total Environ. 2020, 705, 135820. [CrossRef]

16. Xu, M.; Lai, I.K.W.; Tang, H. From Corporate Environmental Responsibility to Purchase Intention of Chinese Buyers: The Mediation Role of Relationship Quality. J. Consum. Behav. 2021, 20, 309-323. [CrossRef]

17. Dagher, G.K.; Itani, O.; Kassar, A.N. The Impact of Environment Concern and Attitude on Green Purchasing Behavior: Gender as The Moderator. Contemp. Manag. Res. 2015, 11, 179-206. [CrossRef]

18. Grimmer, M.; Bingham, T. Company Environmental Performance and Consumer Purchase Intentions. J. Bus. Res. 2013, 66, 1945-1953. [CrossRef]

19. Lai, C.K.M.; Cheng, E.W.L. Green Purchase Behavior of Undergraduate Students in Hong Kong. Soc. Sci. J. 2016, 53, 67-76. [CrossRef]

20. Sharma, A.; Foropon, C. Green Product Attributes and Green Purchase Behavior: A Theory of Planned Behavior Perspective with Implications for Circular Economy. Manag. Decis. 2019, 57, 1018-1042. [CrossRef]

21. Zheng, G.W.; Siddik, A.B.; Masukujjaman, M.; Alam, S.S.; Akter, A. Perceived Environmental Responsibilities and Green Buying Behavior: The Mediating Effect of Attitude. Sustainability 2021, 13, 35. [CrossRef]

22. Jan, I.U.; Ji, S.; Yeo, C. Values and Green Product Purchase Behavior: The Moderating Effects of the Role of Government and Media Exposure. Sustainability 2019, 11, 6642. [CrossRef]

23. Yue, B.; Sheng, G.; She, S.; Xu, J. Impact of Consumer Environmental Responsibility on Green Consumption Behavior in China: The Role of Environmental Concern and Price Sensitivity. Sustainability 2020, 12, 2074. [CrossRef]

24. De Mendonca, T.R.; Zhou, Y. Environmental Performance, Customer Satisfaction, and Profitability: A Study among Large U.S Companies. Sustainability 2019, 11, 5. [CrossRef]

25. Stolz, J.; Molina, H.; Ramírez, J.; Mohr, N. Consumers' Perception of the Environmental Performance in Retail Stores: An Analysis of the German and the Spanish Consumer. Int. J. Consum. Stud. 2013, 37, 394-399. [CrossRef]

26. Nyilasy, G.; Gangadharbatla, H.; Paladino, A. Perceived Greenwashing: The Interactive Effects of Green Advertising and Corporate Environmental Performance on Consumer Reactions. J. Bus. Ethics 2014, 125, 693-707. [CrossRef]

27. Wen, D.; Xiao, T.; Dastani, M. Pricing and Collection Rate Decisions in a Closed-Loop Supply Chain Considering Consumers' Environmental Responsibility. J. Clean. Prod. 2020, 262, 121272. [CrossRef]

28. Naidoo, M.; Gasparatos, A. Corporate Environmental Sustainability in the Retail Sector: Drivers, Strategies and Performance Measurement. J. Clean. Prod. 2018, 203, 125-142. [CrossRef]

29. Bae, H.S. Empirical Relationships of Perceived Environmental Uncertainty, Supply Chain Collaboration and Operational Performance: Analyses of Direct, Indirect and Total Effects. Asian J. Shipp. Logist. 2017, 33, 263-272. [CrossRef]

30. Meinlschmidt, J.; Schaltenbrand, B.; Busse, C.; Förstl, K. Environmental and Sustainable Performance from a Supply Chain Management Perspective. Effic. Logist. 2013, 175-183. [CrossRef]

31. Yang, J.; Han, Q.; Zhou, J.; Yuan, C. The Influence of Environmental Management Practices and Supply Chain Integration on Technological Innovation Performance-Evidence from China's Manufacturing Industry. Sustainability 2015, 7, 15342-15361. [CrossRef]

32. Seman, N.A.A.; Govindan, K.; Mardani, A.; Zakuan, N.; Mat Saman, M.Z.; Hooker, R.E.; Ozkul, S. The Mediating Effect of Green Innovation on the Relationship between Green Supply Chain Management and Environmental Performance. J. Clean. Prod. 2019, 229, 115-127. [CrossRef]

33. Albino, V.; Dangelico, R.M.; Pontrandolfo, P. Do Inter-Organizational Collaborations Enhance a Firm's Environmental Performance? A Study of the Largest U.S. Companies. J. Clean. Prod. 2012, 37, 304-315. [CrossRef]

34. Hazel, D.; Kang, J. The Contributions of Perceived CSR Information Substantiality Toward Consumers' Cognitive, Affective, and Conative Responses: The Hierarchy of Effects Model Approach. Cloth. Text. Res. J. 2018, 36, 62-77. [CrossRef] 
35. Yu, K.; Cadeaux, J.; Song, H. Flexibility and Quality in Logistics and Relationships. Ind. Mark. Manag. 2017, 62, 211-225. [CrossRef]

36. Dang, V.T.; Nguyen, N.; Pervan, S. Retailer Corporate Social Responsibility and Consumer Citizenship Behavior: The Mediating Roles of Perceived Consumer Effectiveness and Consumer Trust. J. Retail. Consum. Serv. 2020, 55, 102082. [CrossRef]

37. Hojat, A.H.M.; Rahim, K.A.; Chin, L. Firm's Environmental Performance: A Review of Their Determinants. Am. J. Econ. Bus. Adm. 2010, 2, 330-338. [CrossRef]

38. Trujillo-Gallego, M.; Sarache, W.; Sellitto, M.A. Environmental Performance in Manufacturing Companies: A Benchmarking Study. Benchmarking 2021, 28, 670-694. [CrossRef]

39. Schultze, W.; Trommer, R. The Concept of Environmental Performance and Its Measurement in Empirical Studies. J. Manag. Control 2012, 22, 375-412. [CrossRef]

40. Davis, F.D. Perceived Usefulness, Perceived Ease of Use, and User Acceptance of Information Technology. MIS Q. Manag. Inf. Syst. 1989, 13, 319-339. [CrossRef]

41. Gatti, L.; Caruana, A.; Snehota, I. The Role of Corporate Social Responsibility, Perceived Quality and Corporate Reputation on Purchase Intention: Implications for Brand Management. J. Brand Manag. 2012, 20, 65-76. [CrossRef]

42. Afzal, H.; Khan, M.A.; ur Rehman, K.; Ali, I.; Wajahat, S. Consumer's Trust in the Brand: Can It Be Built through Brand Reputation, Brand Competence and Brand Predictability. Int. Bus. Res. 2009, 3, 43-51. [CrossRef]

43. Kan, C.W.; Chow, C.Y.T.; Thangtham, U.; Yabdee, S.; Yulek, A.; Mongkholrattanasit, R. Exploring the Relationship between Brand Green Image, Environmental Performance and Consumer Green Consciousness and Purchase Intention of Fashion Products. Appl. Mech. Mater. 2017, 866, 425-432. [CrossRef]

44. Suki, M.N. Green Product Purchase Intention: Impact of Green Brands, Attitude, and Knowledge. Br. Food J. 2016, 118, 2893-2910. [CrossRef]

45. Niesten, E.; Jolink, A.; Lopes de Sousa Jabbour, A.B.; Chappin, M.; Lozano, R. Sustainable Collaboration: The Impact of Governance and Institutions on Sustainable Performance. J. Clean. Prod. 2017, 155, 1-6. [CrossRef]

46. Chan, C.K.; Lee, Y.C.E.; Campbell, J.F. Environmental Performance-Impacts of Vendor-Buyer Coordination. Int. J. Prod. Econ. 2013, 145, 683-695. [CrossRef]

47. Bae, H.S. The Relationships between Environment, Integration and Performance in Supply Chain Contexts Contents. Asian J. Shipp. Logist. 2011, 27, 61-90. [CrossRef]

48. Sozuer, A.; Altuntas, G.; Semercioz, F. Inter-Firm Governance and Relationship Quality: A Study on 3PL Firms. J. Glob. Strateg. Manag. 2015, 1, 29. [CrossRef]

49. Voinea, C.L.; Hoogenberg, B.J.; Fratostiteanu, C.; Hashmi, H.B.A. The Relation between Environmental Management Systems and Environmental and Financial Performance in Emerging Economies. Sustainability 2020, 12, 5309. [CrossRef]

50. Andersen, P.; Weisstein, F.L.; Song, L. Consumer Response to Marketing Channels: A Demand-Based Approach. J. Mark. Channels 2020, 26, 43-59. [CrossRef]

51. Lostakova, H.; Pecinova, Z. The Role of Partnership and Flexibility in Strengthening Customer Relationships in the B2B Market. Procedia-Soc. Behav. Sci. 2014, 150, 563-575. [CrossRef]

52. Sheu, C.; Yen, H.J.R.; Chae, B. Determinants of Supplier-Retailer Collaboration: Evidence from an International Study. Int. J. Oper. Prod. Manag. 2006, 26, 24-49. [CrossRef]

53. Redaelli, E.J.; Paiva, E.L.; Teixeira, R. The Relationship between Manufacturer and Distributors: Knowledge Transfer and Performance. BAR—Braz. Adm. Rev. 2015, 12, 421-441. [CrossRef]

54. Mason, K.; Mouzas, S. Flexible Business Models. Eur. J. Mark. 2012, 46, 1340-1367. [CrossRef]

55. Panigrahi, S.S.; Sahu, B. Analysis of Interactions among the Enablers of Green Supply Chain Management Using Interpretive Structural Modelling: An Indian Perspective. Int. J. Comp. Manag. 2018, 1, 377. [CrossRef]

56. Ryu, S.; Park, J.E.; Min, S. Factors of Determining Long-Term Orientation in Interfirm Relationships. J. Bus. Res. 2007, 60, 1225-1233. [CrossRef]

57. Palmatier, R.W.; Mccabe, E.; Fellow, F.; Foster, M.G. Interfirm Relational Drivers of Customer Value. J. Mark. 2008, 72, 76-89. [CrossRef]

58. Rinehart, L.M.; Eckert, J.A.; Handfield, R.B.; Page, T.J.; Atkin, T. An Assessmtent of Supplier-Cistomer Relationships. J. Bus. Logist. 2004, 25, 25-62. [CrossRef]

59. De Wulf, K.; Odekerken-Schröder, G.; Van Kenhove, P. Investments in Consumer Relationships: A Critical Reassessment and Model Extension. Int. Rev. Retail. Distrib. Consum. Res. 2003, 13, 245-261. [CrossRef]

60. Dewalska-Opitek, A.; Bilińska-Reformat, K. To What Extent Retail Chains' Relationships with Suppliers Make the Business Trustworthy-An Empirical Study on Fast Fashion in Pandemic Times. J. Risk Financ. Manag. 2021, 14, 153. [CrossRef]

61. Stanko, M.A.; Bonner, J.M.; Calantone, R.J. Building Commitment in Buyer-Seller Relationships: A Tie Strength Perspective. Ind. Mark. Manag. 2007, 36, 1094-1103. [CrossRef]

62. Frazier, G.L. Organizing and Managing Channels of Distribution. J. Acad. Mark. Sci. 1999, 27, 226-240. [CrossRef]

63. San, Y.W.; Yazdanifard, R. How Consumer Decision Making Process Differ From Youngster to Older Consumer Generation. J. Res. Mark. 2014, 2, 151. [CrossRef]

64. Victor, V.; Thoppan, J.J.; Nathan, R.J.; Maria, F.F. Factors Influencing Consumer Behavior and Prospective Purchase Decisions in a Dynamic Pricing Environment-An Exploratory Factor Analysis Approach. Soc. Sci. 2018, 7, 153. [CrossRef] 
65. Mostafa, M.M. Gender Differences in Egyptian Consumers' Green Purchase Behaviour: The Effects of Environmental Knowledge, Concern and Attitude. Int. J. Consum. Stud. 2007, 31, 220-229. [CrossRef]

66. Solekah, N.A. Green Marketing Tools, Religiosity, Environmental Attitude And Green Purchase Behaviour Among Millenials Generation. MEC-J Manag. Econ. J. 2020, 4, 233-252. [CrossRef]

67. Albayrak, T.; Aksoy, S..; Caber, M. The Effect of Environmental Concern and Scepticism on Green Purchase Behaviour. Mark. Intell. Plan. 2013, 31, 27-39. [CrossRef]

68. Yeo, G.T.; Thai, V.V.; Roh, S.Y. An Analysis of Port Service Quality and Customer Satisfaction: The Case of Korean Container Ports. Asian J. Shipp. Logist. 2015, 31, 437-447. [CrossRef]

69. Diggle, A.; Walker, T.R. Implementation of Harmonized Extended Producer Responsibility Strategies to Incentivize Recovery of Single-Use Plastic Packaging Waste in Canada. Waste Manag. 2020, 110, 20-23. [CrossRef]

70. Lavergne, K.J.; Sharp, E.C.; Pelletier, L.G.; Holtby, A. The Role of Perceived Government Style in the Facilitation of Self-Determined and Non Self-Determined Motivation for pro-Environmental Behavior. J. Environ. Psychol. 2010, 30, 169-177. [CrossRef]

71. Schuitema, G.; De Groot, J.I.M. Green Consumerism: The Influence of Product Attributes and Values on Purchasing Intentions. J. Consum. Behav. 2014, 14, 57-69. [CrossRef]

72. Tuni, A.; Rentizelas, A.; Duffy, A. Environmental Performance Measurement for Green Supply Chains: A Systematic Analysis and Review of Quantitative Methods. Int. J. Phys. Distrib. Logist. Manag. 2018, 48, 765-793. [CrossRef]

73. Kaiser, F.G.; Wolfing, S.; Fuhrer, U. Environmental Attitude And Ecological Behaviour. J. Environ. Psychol. 1999, 19, 1-19. [CrossRef]

74. Milfont, T.L.; Duckitt, J. The Environmental Attitudes Inventory: A Valid and Reliable Measure to Assess the Structure of Environmental Attitudes. J. Environ. Psychol. 2010, 30, 80-94. [CrossRef]

75. Narula, S.A.; Desore, A. Framing Green Consumer Behaviour Research: Opportunities and Challenges. Soc. Responsib. J. 2016, 12, 1-22. [CrossRef]

76. Biswas, A. A Study of Consumers' Willingness to Pay for Green Products. J. Adv. Manag. Sci. 2016, 4, 211-215. [CrossRef]

77. Fraj, E.; Martinez, E. Ecological Consumer Behaviour: An Empirical Analysis. Int. J. Consum. Stud. 2007, 31, 26-33. [CrossRef]

78. Rosa, C.D.; Collado, S. Experiences in Nature and Environmental Attitudes and Behaviors: Setting the Ground for Future Research. Front. Psychol. 2019, 10, 763. [CrossRef] [PubMed]

79. Khuzaimah, A.B.; Taslim, F.A.; Zabri, I.F.; Jia, K.J.; Ganamoorthi, K.R.; Ling, L.E.; Samah, M.A.A.; Isai, K.I.A.; Muthutamilselvan, K.; Kanan, V.N.; et al. Consumer Behaviour in Green Purchasing: A Case Study in Petaling Jaya, Malaysia. Malays. J. Soc. Sci. Humanit. 2020, 5, 44-59. [CrossRef]

80. Malik, C.; Singhal, N. Consumer Environmental Attitude and Willingness to Purchase Environmentally Friendly Products: An SEM Approach. Vision 2017, 21, 152-161. [CrossRef]

81. Rehman, K.S.A.; Qianli, D.; Yu, Z.; Shahid, K.S. Research on the Development of a Sustainable Green Logistics System from the Perspective of Pakistan. Int. J. Econ. Behav. Organ. 2017, 5, 63. [CrossRef]

82. Young, W.; Davis, M.; McNeill, I.M.; Malhotra, B.; Russell, S.; Unsworth, K.; Clegg, C.W. Changing Behaviour: Successful Environmental Programmes in the Workplace. Bus. Strateg. Environ. 2015, 24, 689-703. [CrossRef]

83. Agarwal, U.; Narayana, S.A. Impact of Relational Communication on Buyer-Supplier Relationship Satisfaction: Role of Trust and Commitment. Benchmarking 2020, 27, 2459-2496. [CrossRef]

84. Joshi, Y.; Rahman, Z. Consumers' Sustainable Purchase Behaviour: Modeling the Impact of Psychological Factors. Ecol. Econ. 2019, 159, 235-243. [CrossRef]

85. Pinto, M.J.A.; Mendes, J.V. Operational Practices of Lean Manufacturing: Potentiating Environmental Improvements. J. Ind. Eng. Manag. 2017, 10, 550-580. [CrossRef]

86. Gao, J.; Zhao, J.; Wang, J.; Wang, J. The Influence Mechanism of Environmental Anxiety on Pro-Environmental Behaviour: The Role of Self-Discrepancy. Int. J. Consum. Stud. 2021, 45, 54-64. [CrossRef]

87. Tabachnick, B.G.; Fidell, L.S. Using Multivariate Statistics, 6th ed.; Pearson Education: Boston, MA, USA, 2013; ISBN 13 978-0-20595622-7.

88. Palinkas, L.A.; Horwitz, S.M.; Green, C.A.; Wisdom, J.P.; Duan, N.; Hoagwood, K. Purposeful Sampling for Qualitative Data Collection and Analysis in Mixed Method Implementation Research. Adm. Policy Ment. Health Ment. Health Serv. Res. 2015, 42, 533-544. [CrossRef]

89. Rawlins, B. Give the Emperor a Mirror: Toward Developing a Stakeholder Measurement of Organizational Transparency. J. Public Relat. Res. 2008, 21, 71-99. [CrossRef]

90. Walsh, G.; Beatty, S.E. Customer-Based Corporate Reputation of a Service Firm: Scale Development and Validation. J. Acad. Mark. Sci. 2007, 35, 127-143. [CrossRef]

91. Newell, S.J.; Goldsmith, R.E. The Development of a Scale to Measure Perceived Corporate Credibility. J. Bus. Res. 2001, 52, 235-247. [CrossRef]

92. Johnson, J.L. Strategic Integration in Industrial Distribution Channels: Managing the Interfirm Relationship as a Strategic Asset. J. Acad. Mark. Sci. 1999, 27, 4-18. [CrossRef]

93. Salazar, H.A.; Oerlemans, L.; Van Stroe-Biezen, S. Social Influence on Sustainable Consumption: Evidence from a Behavioural Experiment. Int. J. Consum. Stud. 2013, 37, 172-180. [CrossRef] 
94. Kulin, J.; Sevä, I.J. The Role of Government in Protecting the Environment: Quality of Government and the Translation of Normative Views about Government Responsibility into Spending Preferences. Int. J. Sociol. 2019, 49, 110-129. [CrossRef]

95. Quoquab, F.; Mohammad, J. Cognitive, Affective and Conative Domains of Sustainable Consumption: Scale Development and Validation Using Confirmatory Composite Analysis. Sustainability 2020, 12, 7784. [CrossRef]

96. Taherdoost, H. Validity and Reliability of the Research Instrument; How to Test the Validation of a Questionnaire/Survey in a Research. Int. J. Acad. Res. Manag. 2016, 5, 28-36. [CrossRef]

97. Hair, J.F.; Sarstedt, M.; Hopkins, L.; Kuppelwieser, V.G. Partial Least Squares Structural Equation Modeling (PLS-SEM): An Emerging Tool in Business Research. Eur. Bus. Rev. 2014, 26, 106-121. [CrossRef]

98. Sarstedt, M.; Ringle, C.M.; Hair, J.F. Partial Least Squares Structural Equation Modeling. Handb. Mark. Res. 2017, 26, 1-40. [CrossRef]

99. Hu, L.T.; Bentler, P.M. Cutoff Criteria for Fit Indexes in Covariance Structure Analysis: Conventional Criteria versus New Alternatives. Struct. Equ. Model. 1999, 6, 1-55. [CrossRef]

100. Vázquez, R.; Iglesias, V.; Álvarez-González, L.I. Distribution Channel Relationships: The Conditions and Strategic Outcomes of Cooperation between Manufacturer and Distributor. Int. Rev. Retail. Distrib. Consum. Res. 2005, 15, 125-150. [CrossRef]

101. Qin, S.; Zhao, L.; Yi, X. Impacts of Customer Service on Relationship Quality: An Empirical Study in China. Manag. Serv. Qual. 2009, 19, 391-409. [CrossRef]

102. Awan, U.; Kraslawski, A.; Huiskonen, J. Governing Interfirm Relationships for Social Sustainability: The Relationship between Governance Mechanisms, Sustainable Collaboration, and Cultural Intelligence. Sustainability 2018, 10, 4473. [CrossRef]

103. Ailawadi, K.L.; Farris, P.W. Managing Multi- and Omni-Channel Distribution: Metrics and Research Directions. J. Retail. 2017, 93, 120-135. [CrossRef] 